YAK 347.4

DOI https://doi.org/10.32837/chc.v0i39.377

\author{
Рим Тарас Ярославович, \\ кандиАат юриАичних наук, \\ СУААя ГоспоАарського сУАу Аьвівської області \\ ORCID ID: 0000-0002-0172-7055
}

\title{
ВІДПОВІДАЛЬНІСТЬ УЧАСНИКІВ ІНВЕСТИЦІЙНИХ ВІДНОСИН У БУДІВНИЦТВІ ЗА ПОРУШЕННЯ ГРОШОВИХ ЗОБОВ'ЯЗАНЬ
}

Вступ. Кредитори застосовують заходи майнової віАповіАальності до боржників у цивільних правовідносинах за порушення грошових зобов'язань чи не найчастіше з-поміж інших способів захисту. Особливості правовідносин учасників інвестиційної Аіяльності полягають у склаАній їхній структурі, яка охоплює як Аоговірні, так і речові права, значну кількість суб'єктів, що не завжАи взаємодіють між собою безпосередньо. 3 огляду на це застосування санкцій за порушення грошових зобов'язань, які неминуче виникають у процесі інвестування, також набуває своїх характерних ознак та правил застосування.

Аналіз Аосліджень. Питання відповідальності учасників цивільних віАносин за порушення грошових зобов'язань Аостатньо широко висвітлювалося в науковій літературі. 3-поміж інших авторів варто викоремити наукові напрацювання І.С. Канзафарової, Р.А. Майданика, В.А. Примака, О.П. Подцерковного, Т.В. БоАнар, І.О. Азери. Проте питання особливостей віАповіАальності учасників інвестиційних віАносин у будівництві $€$ неАостатньо АосліАженим.

Метою статті $€$ виявлення особливостей майнової віАповіАальності учасників інвестиційних віАносин у будівництві за порушення грошових зобов'язань.

ВикиаА основного матеріалу. Порушення грошових зобов'язань в інвестиційних Аоговірних віАносинах має насліАком сплату процентів, інфляційних втрат і пені. ВіАповіАно Ао ч. 2 ст. 625 ЦК України боржник, який прострочив виконання грошового зобов'язання на вимогу кредитора, зобов'язаний оплатити суму боргу з урахуванням встановленого індексу інфляції за весь час прострочення, а також три проценти річних віА простроченої суми, якщо інший розмір процентів не встановлений договором або законом. Пенею є неустойка, що обчислюється у віАсотках віА суми несвоєчасно виконаного грошового зобов'язання за кожний Аень прострочення виконання (ч. 3 ст. 549 ЦК України).

У першу чергу варто зупинитися на проблемах визначення поняття грошових зобов'язань. Річ у тому, що донедавна існували Аискусії стосовно можливості застосування санкцій, передбачених ст. 625 ЦК України, в недоговірних віАносинах. Зокрема, в п. 5.2 Постанови Пленуму Вищого господарського суду України віА 17.12.2013 № 14 "Про Аеякі питання практики застосування законодавства про віАповіАальність за порушення грошових зобов'язань" визначено, що обов'язок боржника сплатити суму боргу 3 урахуванням індексу інфляції та процентів річних не виникає у випадках повернення коштів особі, яка відмовилася віА прийняття зобов'язання за договором (стаття 612 ЦК України), повернення сум авансу та завдатку, повернення коштів у разі припинення зобов'язання (в тому числі шляхом розірвання Аоговору) за згодою сторін або визнання його неАійсним, віАшкоАування збитків та шкоАи, повернення безпіАставно отриманих коштів (стаття 1212 ЦК України), оскільки віАповідні Аії вчиняються сторонами не на виконання взятих на себе грошових зобов'язань, а з інших піАстав [1].

У науковій літературі відображалася протилежна позиція. Так, на підставі ст. 625 цК України можна нараховувати проценти як на Аоговірні, так і на недоговірні зобов'язання, оскільки як перші, так і Аругі можуть полягати в обов'язку виплати певної суми грошей [2, с. 304]. О.П. Подцерковний Аоводив, що положення ст. 625 ЦК України 
поширюються на всі випадки, коли грошове зобов' язання, чи то договірне, чи то позадоговірне, виник^о, але прострочене [3, с. 279]. Аналогічної позиції Аотримується І.О. Азера [4, с. 117].

у широкому розумінні піАставою виникнення грошового зобов'язання є юридичний факт. При цьому юриАичний факт може формуватися як у договірному, так і недоговірному порядку, носити правомірний та неправомірний характер [5, с. 292].

Тому невипадково Верховний Суд змінює попередні позиції вищих судових інстанцій. Зокрема, Аія ст. 625 ЦК України поширюється на всі види грошових зобов'язань незалежно віА підстав їх виникнення (Аоговір чи Аелікт), у тому числі й на позадоговірне грошове зобов'язання, що виникло на підставі ст. 1212 ЦК України. У разі прострочення виконання зобов'язання, зокрема щодо повернення безпідставно одержаних чи збережених грошей, нараховуються 3\% річних та інфляційні нарахування віА простроченої суми відповіАно до ч. 2 ст. 625 ЦК України [6].

У контексті відповіАальності за порушення грошових зобов'язань в інвестиційній сфері будівництва проценти за користування інвестиційними коштами в разі прострочення виконання зобов'язання потрібно вважати негативними майновими наслідками. у ст. 232 ГК України відсотки за неправомірне користування чужими коштами прирівнюються Ао штрафних санкцій і поширюються на випаАки невиконання або неналежно виконання зобов'язання.

Сплата процентів за прострочення виконання грошового зобов'язання і пені можливі за наявності піАстав цивільної віАповіАальності без урахування збитків. Збитки та їх розмір не мають правового значення Аля виникнення обов'язку боржника сплатити проценти та/або неустойку за порушення грошового зобов'язання.

Оскільки згіАно зі ст. 549 ЦК України пеня є різновидом неустойки, то значення Аля визначення розміру збитків має виА неустойки (пені). Йдеться про штрафну, залікову, альтернативну та вик^ючну неустойку. ОАнак наявність чи відсутність збитків не впливає на виникнення охоронного правовіАношення з оплати процентів та пені за порушення інвестиційного зобов'язання. При цьому сплата процентів за прострочення виконання грошового зобов'язання та пені може застосовуватися одночасно в разі порушення зобов'язання.

Пеню, як виА неустойки, законодавець у ст. 549 ЦК України розглядає як виА забезпечення зобов'язання. Натомість згідно зі ст. 231 ГК України неустойка, штраф, пеня, яку учасник господарських відносин зобов'язаний сплатити в разі порушення ним прави^ зАійснення або неналежного виконання господарського зобов'язання, належить до штрафних санкцій. Виходячи зі змісту названої статті пеня, як штрафна санкція, може застосовуватися як у публічних господарських, так і в приватних інвестиційних відносинах. Сплата штрафних санкцій за невиконання або неналежне виконання зобов'язання не звільняє боржника віА виконання зобов'язання в натурі, крім випадків, передбачених законодавством.

Неустойку (штраф, пеню) поряА із видами забезпечення належного виконання зобов'язання потрібно розглядати як різновиА штрафних санкцій за невиконання або неналежне виконання зобов'язань у тому числі в інвестиційній сфері будівництва [8, с. 9]. Свого часу О.А. Пушкін піАкреслював, що заходи цивільно-правової віАповідальності, які застосовуються Ао боржника за порушення зобов'язань, можуть бути віднесені до загальних або спеціальних форм відповідальності. Загальна міра відповідальності застосовується у випадках порушення будь-якого договірного зобов'язання, внаслідок чого вона і розглядається як загальна форма відповідальності. Ао спеціальних форм відповідальності за невиконання або неналежне виконання зобов'язання належать стягнення неустойки (штрафу, пені), деякі інші заходи, наприклаА втрата завдатку [9, с. 417].

Отже, неустойка, штраф, пеня є штрафними санкціями в розумінні спеціальних форм цивільної відповідальності, які встановлені законом або передбачені Аоговором. У судовій практиці склався підхіА, що неустойка має подвійну правову природу. Ао настання строку виконання зобов'язання неустойка $€$ способом забезпечення його належного виконання, а в разі невиконання - перетворюється на відповідальність, яка спрямована на компенсацію негативних Аля кредитора насліАків порушення зобов'язання боржником [10, с. 94].

Пеня $€$ різновидом неустойки, тому виконує аналогічні функції. Верховний СуА у складі колегії судАів Касаційного господарського суду у своїй справі № 917/194/18 зазначив, що такий виА забезпечення виконання зобов'язання, як пеня, та її розмір встановлений ч. 3 ст. 549 ЦК України, ч. 6 ст. 231 ГК України та ст.ст. 1, 3 Закону України "Про відповідальність за несвоєчасне виконання грошових зобов'язань" [11], а право встановити в Аоговорі розмір та порядок нарахування штрафу надано сторонам ч. 4 ст. 231 ГК України. Можливість оАночасного стягнення 
пені та штрафу за порушення окремих вилів господарських зобов'язань передбачено ч. 2 ст. 231 ГК України. При цьому в інших випадках порушення виконання господарських зобов'язань чинне законодавство не встановлює Аля учасників господарських відносин обмежень передбачати в Аоговорі можливість одночасного стягнення пені та штрафу, що узгоджується зі свободою Аоговорів встановленого ст. 627 ЦК України. Тобто сторони є вільними в уклаАенні договору, виборі контрагента та визначенні умов Аоговору з урахуванням вимог ЦК України, інших активів цивільного законодавства, звичаїв Аілового обороту, вимог розумності та справеАмивості. За таких обставин колегія судАів Аійшла висновку, що одночасне стягнення з учасника господарських віАносин, який порушив госпоАарське зобов'язання за Аоговором, штрафу та пені не суперечить ст. 61 Конституції України, оскільки згідно зі ст. 549 ЦК України пеня та штраф є формами неустойка, а відповіАно Ао ст. 230 ГК України - видами штрафних санкцій, тобто не є окремими та самостійними видами юридичної віАповіда^ьності. У межах одного виду відповідальності може застосовуватися різний набір санкцій (наведена правова позиція виклаАена у Постановах Верховного Суду віА 9 ^ютого 2018 р. у справі № 911/2813/17, віА 22 березня 2018 р. у справі № 911/1351/17, віА 25 травня 2018 р. у справі № 922/1720/17) [12].

Потрібно зазначити, що позиція Верховного Суду у склаАі судАів Касаційного цивільного суду $\epsilon$ протилежною [13].

Водночас в юридичній мітературі має місце позиція, яка базується на могіко-юридичному тлумаченні нормативно-правових актів. Аналіз нормативних Ажерел свідчить, що нарахування пені як виду неустойки є єАино передбачуваним виАом віАповіАальності за порушення грошових зобов'язань, та розмір якої обмежується законом і не може змінюватися за домовленістю сторін. Як наслідок, робиться висновок про недопустимість передбачати в Аоговорі стягнення штрафу і пені. Тлумачення ст. 61 Конституції України свідчить, що ії положення спрямовані на недопустимість подвійної відповіда^ьності за одне і те саме порушення. Натомість це не стосується встановлення обсягу віАповіАальності за правопорушення через вк^ючення Ао нього одразу і пені, і штрафу, і процентів річних, аАже це питання перебуває в іншій площині. Обсяг віАповіАальності та подвійність віАповіАальності - це різні правові категорії. Тому видається безпідставним посилання в рішеннях судів на ст. 61 Конституції України піА час Аоведення неможливості стягнення і пені, і штрафу, і процентів річних [14, с. 271].

В інвестиційних відносинах будівництва, на наш погляА, можливим є застосування як пені, так і процентів у разі порушення грошових зобов'язань. Найчастіше це стосується захисту прав інвестора. ААже користування грошовими коштами інвестора у випадку несвоєчасного введення інвестиційного проєкту в дію або взагалі невиконання своїх зобов'язань забудовником (підрядником) є правопорушенням. Право на застосування перелічених санкцій може мати і виконавець будівельних пілрядних робіт у разі несвоєчасного зАійснення обов'язку оплати зі сторони інвестора.

Існують суттєві особливості в інвестуванні за Аопомогою фонду фінансування будівництва. Проблема полягає в тому, що інвестор передає власні кошти в управління відповіАної фінансової установи. Натомість інвестор має право вимагати, а управитель - обов'язок передати інвестору введений в експлуатацію об'єкт нерухомості (цей обов'язок полягає у видачі АовіАки про право Аовірителя на набуття у власність об'єкта інвестування, після чого між інвестором та забуАовником складається акт приймання-передачі об'єкта інвестування). Тобто ця компанія не має грошового зобов'язання переА інвестором, Аопоки обов'язок із передачі нерухомого майна не трансформується у грошовий. Таким чином, у випалку порушення обов'язку з передачі нерухомого майна компанія фактично користується вкладеними коштами, проте підстави Аля стягнення $з$ неї пені (за наявності підстав) чи процентів річних та інфляційних збитків на підставі ст. 625 цК України відсутні.

Інша ситуація склалається у випадку викупу фінансовою установою сетифікатів фонду операцій з нерухомістю. У випадку настання строку Аля їх викупу та Аотримання інвестором усіх правил в управителя виникає грошовий обов'язок, тобто обов'язок виплатити конкретну суму коштів на користь інвестора. У разі порушення вілповідного строку в інвестора виникатиме право на стягнення пені (за наявності підстав) чи процентів річних та інфляційних збитків на підставі ст. 625 цК України.

Спеціальні форми цивільно-правової вілповідальності у вигляАі сплати неустойки (штрафу, пені), стягнення процентів річних, інфляційних витрат застосовуються ^ише у випаАках, спеціально 
передбачених договором або законом. Такі застосовуються винятково в разі порушення прав креАитора в зобов'язанні. А^я покладення на боржника цивільно-правової віАповідальності у вигляАі штрафних санкцій, на віАміну віА збитків, Аостатньою $є$ наявність лише Авох умов: протиправної поведінки та вини боржника [15, с. 503].

Стягнення штрафних санкцій $є$ значно простішим за відшкодування збитків. На відміну віА збитків, розмір неустойки (штрафу, пені), інфляційних витрат, процентів напереА визначений у законі або Аоговорі. Цим пояснюється віАносна простота застосування штрафних санкцій порівняно зі збитками.

Водночас не можна вважати, що штрафні санкції не мають зв'язку з віАшкодуванням збитків. Розмір неустойки може бути зменшений за рішенням суду, якщо він значно перевищує розмір збитків кредитора, а також за наявності інших обставин, які мають істотне значення. Це не виключає домовленості сторін про зменшення розміру неустойки, встановменого актом цивільного законодавства, крім випалків, передбачених законом.

Підставою застосування цивільно-правових способів захисту прав та інтересів $€$ правопорушення. ОАнак його склаА є віАмінним Аля віАшкодування збитків та застосування спеціальних форм відповідальності в цивільному праві.

Загалом специфіка форм відповідальності у цивільному праві дозволяє застосувати одночасно різні із перелічених форм та вихолощує тезу про те, що таке одночасне застосування $€$ порушенням ст. 61 Конституції України, згіАно з якою ніхто не може бути Авічі притягнений Ао юридичної віАповіАальності оАного виду за одне й те саме правопорушення, аАже в Ааному разі йдеться не про застосування різних видів юридичної відповіАальності за одне й те правопорушення, а про застосування різних наслідків майнового характеру в рамках віАповідальності у цивільному праві [16, с. 29].

Власне застосування різних способів захисту Аозволяє повністю або хоча б частково віАновити майновий стан кредитора в інвестиційних відносинах. Недосягнення інвестиційної мети чи неодержання очікуваного Аоходу можливо компенсувати за допомогою віАновлювальних способів захисту. ОАне і те саме правопорушення може мати різні негативні наслідки. Залежно віА його характеру застосовуються вінновлювально-компенсаційні цивільно-правові способи захисту.

ВіАновлювально-компенсаційні способи захисту стимулюють учасників інвестиційних віАносин
Ао належної поведінки, спрямованої на виконання Аоговірних зобов'язань. ВіАновлення становища насампереА стосується майнового стану кредитора - учасника інвестиційних відносин, але не виключена компенсація моральної (немайнової) шкоди інвесторам - фізичним особам.

Відновлення майнового стану учасника інвестиційного процесу не завжди пов'язується із цивільною вілповідальністю Аля порушника. Повернення інвестованих коштів інвестору не $€$ покладенням Аодаткового обов'язку Аля боржника. Цивільно-правовою віАповіАальністю Аля нього буде покладення Аодаткового обов'язку у вигляді віАшкоАування збитків або сплати штрафних санкцій.

Інвестиційний процес у будівництві характеризується тривалістю у часі і має на меті отримати у власність інвестиційний об'єкт або дохіА віА його експлуатації. Але як у першому, так і в Аругому випалках визначальним $€$ виконання інвестиційного Аоговору в натурі. Тому учасники інвестиційного процесу в будівництві, насамперед інвестор, безперечно зацікавлені в Аосягненні інвестиційного результату. Припинення Аоговірних віАносин, як правило, не задовольняє інвестора і не є ефективним засобом захисту та охорони його інтересів.

Висновки. Законодавець надає можливість кредитору застосувати Ао порушника грошового зобов'язання різний набір штрафних санкцій, який охоп^ює стягнення 3\% річних, інфляційних збитків, штрафу, пені.

Управитель фонду фінансування будівництва не має грошового обов'язку піА час виконання Аоговору про участь інвестора у цьому фонді. Відтак застосувати Ао нього штрафні санкції за порушення грошового зобов'язання неможмиво, поки цей обов'язок не трансформується в зобов'язання повернення внесеного інвестиційного вкладу. Натомість в управителя фонду операцій із нерухомістю у випадку настання віАповіАного строку (чи іншої обставини) виникає обов'язок викупити сертифікати фонду, тобто грошовий обов'язок.

Стимулюючим фактором виконання інвестиційних зобов'язань буде примус Ао виконання інвестиційних зобов'язань порушником піА загрозою застосування Ао нього негативних майнових наслідків. 3 іншого боку, віАшкодування збитків, немайнової (моральної) шкоди, штрафних санкцій у вигляАі неустойки (штрафу, пені), процентів та інфляційних втрат $€$ компенсаційним засобом Аля кредитора. 


\section{МITEPATУPA:}

1. Про деякі питання практики застосування законодавства про відповідальність за порушення грошових зобов'язань: постанова Пленуму Вищого господарського суду України від 17.12.2013 № 14. Дата оновлення: 16.12.2015. URL : https://zakon.rada.gov.ua/laws/show/v0014600-13\#Text (дата звернення: 12.10.2020).

2. Рим Т.Я. Недоліки застосування судами норм про стягнення відсотків (процентів річних) у господарських відносинах. Актуальні питання реформування правової системи Украӥни. Збірник наукових статей за матеріалами III міжнародної науково-практичної конференції, м. Луцьк, 2-3 червня 2006 року. Луцьк : РВВ «Вежа» Волин. держ. ун-ту ім. Лесі Українки, 2006. С. 302-307.

3. Подцерковний О.П. Щодо необхідності врахування теорії грошових зобов'язань у практиці вирішення господарських спорів. Наукові праці Нач. ун-ту «Одеська юридична академія». 2013. Т. 13. С. 271-282.

4. Дзера І.О. Правова природа 3 \% річних за статтею 625 ЦК України. Наукові записки НаУКМА: Юридичні науки. 2016. Т. 181. С. 116-120.

5. Безклубий І.А. Цивілістична природа платіжного зобов'язання. Цивільне право Украйни: нові виклики і перспективи розвитку: матеріали XVIII міжн. наук.-практ. конф., присвяч. 98-й річниці з дня народж. д.ю.н., проф., В. П. Маслова, Харків, 28 лют. 2020 р. Харків : Право, 2020. С. 290-293.

6. Постанова Великої Палати Верховного Суду № 910/10156/17 від 10.04.2018. URL : http://reyestr.court.gov.ua/ Review/73627931 (дата звернення: 10.10.2020).

7. Постанова Верховного Суду № 910/13238/18 від 04.12.2019. URL : http://reyestr.court.gov.ua/Review/86141169 (дата $3 в е р-$ нення: 10.10 .2020$)$.

8. Отраднова О.О. Неустойка в цивільному праві : дис. ... канд. юрид. наук : 12.00.03. Київ, 2002. 20 с.

9. Гражданское право Украины : учеб. в 2 ч. Ч. 1. / Под ред. проф. А.А. Пушкина, доц. В.М. Самойленко. Харьков : Основа, 1996. $440 \mathrm{c}$.

10. Синєгубов О.В. Стягнення пені та штрафу за порушення грошового зобов'язання: сучасні тенденції правозастосування. Проблеми цииільного права та процесу: тези доп. учасників наук.-практ. конф., присвяч. світлій пам'яті О.А. Пушкіна, Харків, 24 травня 2019 р. Харків, 2019. С. 94-97.

11. Про відповідальність за несвоєчасне виконання грошових зобов’язань : Закон України від 22.11.1996 р. № 543/96-BР. Дата оновлення: 11.07.2013. URL : https://zakon.rada.gov.ua/laws/show/543/96-\%D0\%B2\%D1\%80\#Техt (дата звернення: 11.07.2020).

12. Постанова Верховного Суду № 917/194/18 від 02.04.2019. URL : http://www.reyestr.court.gov.ua/Review/80923003 (дата 3 вернення: 12.10 .2020$)$.

13. Постанова Верховного Суду № 192/1361/15-ц від 11.12.2019. URL : http://www.reyestr.court.gov.ua/Review/86435400 (дата звернення: 12.10.2020).

14. Відповідальність у приватному праві: монографія / І. Безклубий, Н. Кузнєцова, Р. Майданик та ін. ; за заг. ред. І. Безклубого. Київ : Грамота, 2014. 416 с.

15. Договірне право України. Загальна частина : навч. посібник / за ред. О.В. Дзери. Київ : Юрінком Інтер, 2018.896 с.

16. Зозуляк О.І. Сучасний стан та тенденції розвитку вчення про цивільно-правову відповідальність. Цивільне право України: нові виклики і перспективи розвитку: матеріали XVIII міжн. наук.-практ. конф., присвяч. 98-й річниці 3 дня народж. д.ю.н., проф., В. П. Маслова, Харків, 28 лют. 2020 р. Харків, 2020. С. 27-31.

\section{Рим Тарас Ярославович}

\section{ВІАПОВІААЛЬНІСТЬ УЧАСНИКІВ ІНВЕСТИЦІЙНИХ ВІАНОСИН У БУАІВНИЦТВІ ЗА ПОРУШЕННЯ ГРОШОВИХ ЗОБОВ'ЯЗАНЬ}

Стаття присвячена особливостям цивільно-правової віАповіАальності учасників інвестиційних віАносин в будівництві. На підставі аналізу судових рішень та наукових праць учених-цивілістів автор робить висновок, що поняття грошових зобов'язань охоплює собою обов'язок сплатити грошові кошти як у межах Аоговірних, так і в межах недоговірних зобов'язань.

У статті автор відзначає, що збитки та їх розмір не мають правового значення Аля виникнення обов'язку боржника сплатити проценти та/або неустойку за порушення грошового зобов'язання.

Автор детально аналізує протилежні позиції Верховного Суду в частині можливості одночасного стягнення пені та штрафу за порушення грошового зобов'язання. Аналізує позиції учених із цього питання та обгрунтовує висновок про можливість одночасного стягнення пені та штрафу. Зокрема, застосування різних способів захисту Аозволяє повністю або хоча б частково відновити майновий стан кредитора в інвестиційних відносинах.

У цивільних віАносинах, що виникають під час інвестування за допомогою механізмів фонду фінансування будівництва та фонду операцій із нерухомістю, мають місце суттєві особливості. ААже в управителя фонду фінансування будівництва існує к^ючовий обов'язок - ефективно здійснювати управління коштами інвестора $з$ метою надання останньому об'єкта інвестування. Зазначений обов'язок не є грошовим. Натомість в управителя фонду операцій із нерухомістю піА час настання віАповідного строку виникає обов'язок викупити сертифікати фонду, тобто грошовий обов'язок.

У статті автор розмежовує підстави та умови Аля відшкодування збитків та стягнення штрафних санкцій, які $€$ спеціальною формою цивільно-правової відповідальності.

Автор зазначає, що відновлення майнового стану учасника інвестиційного процесу не завжди пов'язується із цивільною відповіАальністю Аля порушника. Повернення інвестованих коштів інвестору не є покладенням додат- 
кового обов'язку Аля боржника. Цивільно-правовою віАповідальністю Аля нього буде покладення Аодаткового обов'язку у вигляді віАшкодування збитків або сплати штрафних санкцій.

Киючові слова: грошове зобов'язання, порушення зобов'язання, штрафні санкції, інфляційні збитки, неустойка.

\section{Rym Taras \\ RESPONSIBILITY OF INVESTMENT RELATIONS PARTICIPANTS IN CONSTRUCTION FOR VIOLATION OF MONETARY OBLIGATIONS}

The article is devoted to the peculiarities of civil liability of participants in investment relations in construction. Based on the analysis of court decisions and scientific theoretical works, the author concludes that the concept of monetary obligations includes the obligation to pay money, both within the contractual and non-contractual obligations.

The author notes that the losses and their amount have no legal significance for the debtor's obligation to pay interests or penalties for violation of monetary duty.

The author thoroughly analyzes the Supreme Court's opposing positions regarding the possibility of simultaneous collection of fines and penalties for breach of monetary obligation. He explores the works of scientists on this issue and substantiates the possibility of simultaneous collection of fines and penalties. In particular, the use of various protection methods allows to wholly or at least partially restore the property status of the creditor in the investment relationship.

There are significant peculiarities in civil relations that arise when investing using the construction financing fund mechanisms and the real estate operations fund. After all, the construction financing fund manager has a crucial responsibility - to manage the investor's funds effectively to provide the latter with the object of investment. This obligation is not monetary. Instead, the real estate fund manager has a responsibility to redeem the fund's certificates, i.e., a financial commitment.

In the article, the author distinguishes the grounds and conditions for damages compensation and penalties, particular forms of civil liability.

The author notes that the restoration of a participant's property status in the investment process is not always associated with civil liability for the violator. The return of the invested funds to the investor is not an additional obligation for the debtor. He shall carry civil responsibility via taking an accessory obligation in the form of damages or penalties.

Key words: monetary obligation, breach of duty, penalties, inflation losses, penalty. 